\title{
CARDIOVASCULAR RISK FACTORS IN WOMEN OF DIFFERENT AGE AND EXERCISE TRAINING STATUS
}

\author{
Sasa Plecevic ${ }^{1}$, Dusica Djordjevic ${ }^{1}$, Djordje Stefanovic ${ }^{1}$, Milena Vuleticl, Nevena Barudzicl, Vladimir Zivkovic ${ }^{1}$, \\ Dragan Djuric ${ }^{2}$, Tomislav Nedeljkovic ${ }^{3}$ and Vladimir Jakovljevic ${ }^{1}$ \\ ${ }^{1}$ Department of Physiology, Faculty of Medicine, University of Kragujevac, Kragujevac, Serbia \\ 2Institute of Physiology „,Richard Burian“, School of Medicine, Belgrade, Serbia \\ ${ }^{3}$ Central Biochemical Laboratory, Clinical Centre „, Kragujevac”, Kragujevac, Serbia
}

\section{KARDIOVASKULARNI FAKTORI RIZIKA KOD ŽENA RAZLIČITE STAROSTI I TRENAŽNOG STATUSA}

\author{
Saša Plećevićl, Dušica Đorđevićl, Đorđe Stefanovićl, Milena Vuletićl, Nevena Barudžićl, Vladimir Živkovićl, \\ Dragan Đurić2 ${ }^{2}$ Tomislav Nedeljković ${ }^{3}$ and Vladimir Jakovljevićl \\ ${ }^{1}$ Katedra za fiziologiju, Medicinski fakultet, Univerzitet u Kragujevcu, Kragujevac \\ 2Institut za fiziologiju „,Rihard Burijan“, Medicinski fakultet, Univerzitet u Beogradu, Beograd \\ ${ }^{3}$ Centralna biohemijska laboratorija, Klinički centar "Kragujevac”, Kragujevac
}

\section{ABSTRACT}

Objective. Since it has been clearly shown that the prevalence and the incidence of cardiovascular diseases increase with age, the aim of our study was to assess the potential of exercise training, as one of the of the major modifiable behavioral risk factors which greatly affects a number of physiological cardiovascular risk factors, in reducing the effects of aging on cardiovascular risk profiles in women.

Method. A group of 44 women who exercised regularly and 34 age-matched women who performed no physical activity, all of whom were aged between 21 and 60 years, were subjected to morphofunctional testing and blood sampling. Measurement of body composition was performed by using an apparatus for bioelectrical impedance analysis BC-551 InnerScan Body Composition Monitor. The participants were subjected to a maximal progressive exercise test on a treadmill Technogym Excite Jog 500 by using Bruce's protocol. Plasma lipid status (total cholesterol, high density lipoprotein, low density lipoprotein, triglycerides) was analyzed.

Results. The results of our study showed that regular exercise positively influences aerobic capacity and weight of women, but it does not alleviate the influence of aging on majority of morfo-functional and physiological risk factors (the increase of total cholesterol, low density lipoprotein, triglycerides, body mass index, visceral fat and decrease of aerobic capacity with age). After the age of 40 and especially after the age of 50, women experience significant rise of cardiovascular risk factors no matter if they exercise or not.

Conclusion. The results of this cross sectional research showed that there is no significantly positive effect of exercise on cardiovascular risk profile of aging women.

Keywords: exercise; risk factors; cardiovascular diseases; lipoproteins; women.

\section{SA ŽETAK}

Cilj. Obziom da su prethodna istraživanja jasno pokazala da prevalenca i incidenca kardiovaskularnih oboljenja raste sa starenjem, cilj našeg rada bio je da utvrdimo potencijal redovnog vežbanja, kao jednog od najvećih modifikujućih bihevioralnih faktora rizika koji značajno utiče na niz fizioloških kardiovaskularnih faktora rizika, u ublažavanju efekata starenja na kardiovaskularni risk-profil žena.

Metod. Grupa od 44 žene koje redovno vežbaju $i 34$ sedentarne žene sličnog godišta, sve u životnom dobi od 21 do 60 godina, podvrgnute su morfofunkcionalnom testiranju $i$ uzimanju uzorka krvi. Merenje telesne kompozicije je urađeno korišćenjem aparata za analizu bioelektrične impedanse "BC-551 InnerScan Body Composition Monitor". Učesnici su bili podvrgnuti testu maksimalnog progresivnog vežbanja na traci "Technogym Excite Jog 500" koristeći protokol po Brusu. Analiziran je lipidni status (ukupni holesterol, lipoproteini visoke gustine, lipoproteini niske gustine, trigliceridi) u plazmi.

Rezultati. Rezultati studije su pokazali da redovno vežbanje ima pozitivan uticaj na aerobni kapacitet $i$ telesnu masu žena, ali ne može sprečiti uticaj starenja na većinu morfofunkcionalnih i fizioloških kardiovaskularnih faktora rizika (povećanje nivoa ukupnog holesterola, lipoproteina male gustine, triglicerida, visceralne masti, indeksa telesne mase i smanjenje aerobnog kapaciteta). Vežbale ili ne, nakon 40-te i posebno 50-te godine, žene doživljavaju značajno pogoršanje svog kardiovaskularnog risk-profila.

Zaključak. Rezultati ove studije preseka su pokazali da ne postoji statistički značajan pozitivan efekat fizičke aktivnosti na kardiovaskularni rizik profil žena starijeg životnog doba.

Ključne reči: vežbanje; faktori rizika; kardiovaskularne bolesti; lipoproteini; žene. 


\section{INTRODUCTION}

Cardiovascular diseases (CVD), a group of disorders of the heart and blood vessels, represent the major cause of death of both men and women throughout the world. About $55 \%$ of all female deaths and about $43 \%$ of male deaths in Europe are caused by CVD (1). Advances in our understanding of the pathophysiology of cardiovascular diseases have led to a reduction in CVDs and related diseases, but to date cardiovascular illnesses remain among the leading causes of morbidity and mortality in the world. Genetic factors and age are proven risks but other factors, such as hypertension, insulin resistance, hypercholesterolemia, diabetes, and lifestyle factors (e.g. poor diet, smoking and physical inactivity) are also important (2).

Regular physical activity undoubtedly has numerous health-enhancing effects. From the early work of Morris and colleagues in the 1950s $(3,4)$, via the investigations of Blair, Paffenbarger and colleagues in 1980s and 1990s (58) until today, numerous studies have shown a positive correlation between physical activity, physical fitness and the relative risk of a number of diseases and early death (914). These findings and results of the studies that showed biologically reasonable cardioprotective pathways provided the evidence that regular physical activity reduces the incidence of major CVD events, pointing to the physical inactivity as a major CVD risk (2). Nevertheless, the Norwegian epidemiologist Gunnar Erikssen asserts that "modern day humans are dying because of a lack of physical exercise" (15).

Since the results of studies showed that the CVDs increased with age (16), and having in mind that physical activity represents one of the major modifiable behavioral risk factors which greatly affects a number of physiological CVD risk factors and improves overall CVD risk profile, the aim of our study was to assess the potential of exercise training in reducing the effects of aging on cardiovascular risk profiles in women.

\section{SUBJECTS AND METHODS}

A group of 44 female members of "Elit" fitness club (Kragujevac) who exercised regularly (experimental group) and 34 age-matched women who performed no physical activity (control group) took part in this research. All members of the experimental group had been performing a mix of aerobic and strength training 3-5 times a week for more than 3 months in continuity before the beginning of the study (average duration of regular exercising: $16.74 \pm 2.86$ months). Secondly, subjects were classified into 4 groups according to their age (women who were $20-30,30-40,40-50$ and 50-60 years old). Seven out of thirteen oldest women were in menopause.
All subjects were healthy, non-smokers, had no eating disorders and used no medication or supplementation. They were instructed to abstain from any physical activity 24 hours prior to testing and received the same diet 48 hours prior to testing. All participants gave a written informed consent. The study was approved by the Ethical Committee of the Medical Faculty, University of Kragujevac.

The research protocol started at $7 \mathrm{AM}$. After the participants had filled in the standard medicine questionnaire, their blood pressure was measured and they were taken a blood sample from an antecubital vein. Then, measurement of body composition was performed by using an apparatus for bioelectrical impedance analysis BC-551 InnerScan Body Composition Monitor (Tanita, Japan). Measurement was performed according to the manufacturer's instructions. Body weight was measured with the accuracy within $0.1 \mathrm{~kg}$ and body fat with the accuracy of $0.1 \%$. Body height was measured by means of an anthropometer and the results of the measurements were accurate within $0.1 \mathrm{~cm}$.

After the anthropometrical measurement and blood sampling, the subjects had light and lean breakfast and after an hour of rest they were subjected to a maximal progressive exercise test on a treadmill Technogym Excite Jog 500 (Technogym, Italy) by using Bruce's protocol (17). Subjects were familiarized to testing procedure. The exercise test was performed until exhaustion or until the moment when subjects stated their subjective feeling of exhaustion by using Borg's CR10 exhaustion scale of at least 8 (18). Maximal oxygen consumption (VO2max) was determined by an indirect method by using the following equation (19): $\mathrm{VO} 2 \max =2.327$ (time) +9.48 .

Blood samples were taken from an antecubital vein into Vacutainer test tube. After transportation of the samples to the laboratory (in a fridge), blood was centrifuged to separate sera and red blood cells (RBCs) and plasma lipid status (total cholesterol, high density lipoprotein, low density lipoprotein, triglycerides) was analyzed by using routine laboratory protocols in the Central Biochemical Laboratory of Clinical Centre Kragujevac.

The statistical analysis was performed with SPSS 19.0 for Windows. The results are expressed as means \pm standard error of the mean (median). The significance of the influence of the training status and age and combination of these factors (training status*age) was assessed by using Two-way ANOVA and Bonferroni post hoc test. The significance level was set at $\mathrm{P}<0.05$.

\section{RESULTS}

Levels of cardiovascular risk factors in subjects who do and do not exercise are shown in table 1, while levels of these parameters in subjects of different age are shown in table 2 . 
Table 1. Cardiovascular risk factors in controls and subjects who exercise.

\begin{tabular}{|l|c|c|}
\hline Parameter* & Controls $(\mathrm{n}=34)$ & Exercisers $(\mathrm{n}=44)$ \\
\hline Age $($ years $)$ & $35.73 \pm 1.57(35.00)$ & $34.59 \pm 1.82(35.00)$ \\
\hline Height $(\mathrm{cm})$ & $170.25 \pm 1.38(170.00)$ & $64.42 \pm 1.98(65.35)$ \\
\hline Weight $(\mathrm{kg})$ & $68.03 \pm 2.13(65.35)$ & $22.22 \pm 0.62(21.95)$ \\
\hline BMI $\left(\mathrm{kg} / \mathrm{m}^{2}\right)$ & $23.56 \pm 0.62(22.58)$ & $23.54 \pm 1.77(23.10)$ \\
\hline Fat $(\%)$ & $25.45 \pm 1.27(23.85)$ & $3.15 \pm 0.39(3.50)$ \\
\hline Visceral fat $(\%)$ & $4.17 \pm 0.61(2.50)$ & $37.89 \pm 0.68(38.21)$ \\
\hline VO ${ }_{2} \mathrm{max}(\mathrm{ml} / \mathrm{kg} / \mathrm{min})$ & $33.60 \pm 0.71(33.30)$ & $124.24 \pm 2.55(124.00)$ \\
\hline Systolic pressure $(\mathrm{mmHg})$ & $119.69 \pm 2.02(119.00)$ & $80.44 \pm 1.98(80.00)$ \\
\hline Diastolic pressure $(\mathrm{mmHg})$ & $77.81 \pm 1.54(78.00)$ & $5.02 \pm 0.23(4.82)$ \\
\hline Total cholesterol $(\mathrm{mmol} / \mathrm{l})$ & $5.39 \pm 0.16(5.10)$ & $1.41 \pm 0.05(1.40)$ \\
\hline HDL (mmol/l) & $1.30 \pm 0.03(1.30)$ & $3.15 \pm 0.23(2.95)$ \\
\hline LDL (mmol/l) & $3.63 \pm 0.14(3.32)$ & $1.01 \pm 0.06(1.01)$ \\
\hline Triglycerides (mmol/l) & $1.01 \pm 0.06(0.89)$ & \\
\hline
\end{tabular}

${ }^{*} \mathrm{X} \pm \mathrm{SE}($ median)

Table 2. Cardiovascular risk factors subjects of different age.

\begin{tabular}{|l|c|c|c|c|}
\hline Parameter* & $\begin{array}{c}21-30 \text { years } \\
(\mathrm{n}=27)\end{array}$ & $\begin{array}{c}31-40 \text { years } \\
(\mathrm{n}=21)\end{array}$ & $\begin{array}{c}41-50 \text { years } \\
(\mathrm{n}=17)\end{array}$ & $\begin{array}{c}51-60 \text { years } \\
(\mathrm{n}=13)\end{array}$ \\
\hline Height $(\mathrm{cm})$ & $171.30 \pm 1.36(169.00)$ & $170.64 \pm 2.22(171.00)$ & $168.66 \pm 1.16(168.00)$ & $167.11 \pm 2.08(165.00)$ \\
\hline Weight $(\mathrm{kg})$ & $63.83 \pm 1.99(63.50)$ & $65.95 \pm 3.45(64.05)$ & $66.52 \pm 3.03(67.15)$ & $74.71 \pm 3.93(69.70)$ \\
\hline BMI $\left(\mathrm{kg} / \mathrm{m}^{2}\right)$ & $21.71 \pm 0.54(21.72)$ & $22.58 \pm 0.95(22.11)$ & $23.33 \pm 0.93(23.10)$ & $26.64 \pm 0.90(26.23)$ \\
\hline Fat $(\%)$ & $24.64 \pm 1.49(22.55)$ & $22.25 \pm 2.13(23.05)$ & $22.44 \pm 2.07(20.25)$ & $33.02 \pm 1.41(34.60)$ \\
\hline Visceral fat $(\%)$ & $1.95 \pm 0.29(1.50)$ & $2.92 \pm 0.43(2.50)$ & $5.00 \pm 0.69(5.50)$ & $8.00 \pm 1.33(7.00)$ \\
\hline VO ${ }_{2} \mathrm{max}(\mathrm{ml} / \mathrm{kg} / \mathrm{min})$ & $37.06 \pm 0.68(38.21)$ & $36.15 \pm 0.87(36.84)$ & $33.83 \pm 1.21(31.36)$ & $28.46 \pm 1.85(26.80)$ \\
\hline Systolic pressure (mmHg) & $122.22 \pm 2.36(121.00)$ & $116.33 \pm 3.53(116.00)$ & $122.52 \pm 2.36(121.00)$ & $129.80 \pm 5.67(124.00)$ \\
\hline Diastolic pressure (mmHg) & $79.85 \pm 1.97(78.00)$ & $75.04 \pm 2.51(75.00)$ & $79.11 \pm 2.45(79.00)$ & $84.20 \pm 2.82(83.00)$ \\
\hline Total cholesterol (mmol/1) & $4.83 \pm 0.19(4.60)$ & $5.15 \pm 0.22(5.01)$ & $5.41 \pm 0.27(5.16)$ & $6.37 \pm 0.35(6.37)$ \\
\hline HDL (mmol/l) & $1.34 \pm 0.03(1.31)$ & $1.41 \pm 0.06(1.35)$ & $1.25 \pm 0.05(1.27)$ & $1.29 \pm 0.08(1.32)$ \\
\hline LDL (mmol/l) & $3.10 \pm 0.17(2.95)$ & $3.29 \pm 0.22(2.98)$ & $3.71 \pm 0.24(3.54)$ & $4.36 \pm 0.30(4.25)$ \\
\hline Triglycerides (mmol/1) & $0.85 \pm 0.06(0.75)$ & $0.99 \pm 0.08(0.92)$ & $1.00 \pm 0.07(1.01)$ & $1.57 \pm 0.10(1.58)$ \\
\hline
\end{tabular}

\section{* $\mathrm{X} \pm \mathrm{SE}($ median)}

The influence of age, training status and combination of these factors on levels of cardiovascular risk factors investigated in this research was assessed by Two-way ANOVA and the results of this analysis are shown in Table 3. It can be noticed from the table 3 that training status (exercising or not) influences only two parameters weight and aerobic capacity of subjects (subjects who exercise have lower weight and higher aerobic capacity), while age influences 6 investigated parameters - body mass index, visceral fat, aerobic capacity, total cholesterol, LDL and triglycerides. Post hoc analysis (Bonferroni) showed that:

- Weight increased with aging, but statistically significant difference was found only between subjects who were 51-60 years old and subjects who were 2130 years old $(\mathrm{P}=0.042)$;

- Body mass index increased with aging, but statistically significant differences were found only between 
Table 3. The influence of training status, age and combination of these factors (training status*age) on levels of cardiovascular risk factors.

\begin{tabular}{|l|c|c|c|}
\hline Parameter & Training status & Age & Training status Age \\
\hline Height & $\mathrm{P}=0.719$ & $\mathrm{P}=0.354$ & $\mathrm{P}=0.310$ \\
\hline Weight & $\mathrm{P}=0.031$ & $\mathrm{P}=0.397$ & $\mathrm{P}=0.236$ \\
\hline BMI & $\mathrm{P}=0.075$ & $\mathrm{P}=0.035$ & $\mathrm{P}=0.247$ \\
\hline Fat percentage & $\mathrm{P}=0.086$ & $\mathrm{P}=0.075$ & $\mathrm{P}=0.090$ \\
\hline Visceral fat & $\mathrm{P}=0.100$ & $\mathrm{P}<0.001$ & $\mathrm{P}=0.142$ \\
\hline $\mathrm{VO}_{2}$ max & $\mathrm{P}<0.001$ & $\mathrm{P}<0.001$ & $\mathrm{P}=0.199$ \\
\hline Systolic pressure & $\mathrm{P}=0.325$ & $\mathrm{P}=0.139$ & $\mathrm{P}=0.567$ \\
\hline Diastolic pressure & $\mathrm{P}=0.629$ & $\mathrm{P}=0.167$ & $\mathrm{P}=0.231$ \\
\hline Total cholesterol & $\mathrm{P}=0.175$ & $\mathrm{P}=0.018$ & $\mathrm{P}=0.454$ \\
\hline HDL & $\mathrm{P}=0.229$ & $\mathrm{P}=0.214$ & $\mathrm{P}=0.800$ \\
\hline LDL & $\mathrm{P}=0.134$ & $\mathrm{P}=0.024$ & $\mathrm{P}=0.326$ \\
\hline Triglycerides & $\mathrm{P}=0.702$ & $\mathrm{P}=0.004$ & $\mathrm{P}=0.515$ \\
\hline
\end{tabular}

subjects who were 50-60 years old and: 1) subjects who were 21-30 years old $(\mathrm{P}=0.001), 2)$ subjects who were $31-40$ years old $(\mathrm{P}=0.013)$;

- Visceral fat percentage increased with aging and following statistically significant differences were found: 1) the oldest subjects (50-60 years old) had higher levels of visceral fat than all other groups of younger subjects (50-60 vs $21-30$ : $\mathrm{P}<0.001 ; 50-60$ vs 31-40: $\mathrm{P}<0.001 ; 50-60$ vs 40-50: $\mathrm{P}=0.005)$, 2) levels of visceral fat were increased in subjects 41-50 years old compared to subjects 21-30 years old $(\mathrm{P}<0.001)$

- Aerobic capacity decreased with age and statistically significant differences were found between: 1) 20-30 years old and 41-50 years old subjects $(\mathrm{P}=0.037), 2)$ 21-30 years old and 50-60 years old subjects $(\mathrm{P}<0.001), 3) 31-40$ years old and 50-60 years old subjects $(\mathrm{P}<0.001), 4) 41-50$ years old vs $50-60$ years old subjects $(\mathrm{P}=0.008)$;

- Levels of total cholesterol increased with ageing and statistically significant difference was found between the oldest subjects (50-60 years old) and 1) subjects who were 21-30 years old $(\mathrm{P}<0.001), 2)$ subjects who were 31-40 years old $(\mathrm{P}=0.004), 3)$ subjects who were $41-50$ years old $(\mathrm{P}=0.023)$;

- Levels of low density lipoprotein increased with age and statistically significant difference was found between the oldest subjects (50-60 years old) and 1) subjects who were 21-30 years old $(\mathrm{P}=0.001), 2)$ subjects who were $31-40$ years old $(\mathrm{P}=0.009)$;

- Levels of triglycerides increased with age and statistically significant difference was found between the oldest subjects (50-60 years old) and 1) subjects who were 21-30 years old $(\mathrm{P}<0.001), 2)$ subjects who were $31-40$ years old $(\mathrm{P}=0.003), 3)$ subjects who were 41-50 years old $(\mathrm{P}=0.002)$.

The combination of investigated factors (training status*age) showed no significant influence on any of investigated cardiovascular risk factors (Table 3 ).

\section{DISCUSSION}

CVD risk factors can be classified as major, conditional and predisposing risk factors. The independent risk factors for CVD are hypertension, smoking, elevated total serum cholesterol and low-density lipoprotein cholesterol (LDL), low serum high-density lipoprotein cholesterol (HDL), diabetes mellitus, and older age (19). The additional risks, associated with increased risk for CVD, but without proven independent casual relationships are: obesity, physical inactivity, family history of premature CVD, ethnic background and psychosocial issues (19). Elevated serum triglycerides, elevated serum homocysteine, elevated serum lipoprotein, prothrombotic factors and inflammatory markers are considered as the predisposing risk factors (19).

Many consider physical inactivity to be one of the major environmental factors that increase the incidence of cardiovascular diseases (20). The exact magnitude of the effect of inadequate physical inactivity in cardiovascular risk profile is still uncertain. Epidemiological studies have shown that the relative risk of developing CVD and subsequent mortality is $30-50 \%$ lower in physically active and physically fit persons compared with sedentary individuals $(21,22)$, which is addressed to the positive effects of exercise on all above-mentioned cardiovascular risk factors (23-27). 
Having in mind all the above mentioned, we tried to explore the cardiovascular risk profile of women of different age and training status. Although Table 1 shows that there are differences between controls and exercisers in majority of investigated parameters, statistical analysis showed that physical activity significantly affected only two investigated parameters: weight and aerobic capacity. On the other side, 6 investigated parameters were affected by age (body mass index, visceral fat, aerobic capacity, total cholesterol, LDL and triglycerides).

Older age is a significant risk factor for both males and females. However women develop CVD much later (about a decade) than their male counterparts (16). Women have a lower risk of cardiac events during the fertile age but this protection fades in later life. At the age of 45-54 years (menopause) women with untreated risk factors are at increased risk for CVD (1). In addition, the age influences the risk-profile differences between men and women. Total cholesterol levels in women peak between 55 and 65 years of age, about a decade later than in men (29). The results of our research are in accordance with this, since post hoc analysis showed that the only statistically significant difference in cholesterol levels was seen between the groups of women aged 50-60 and all other groups of younger women. This was also the case for triglycerides. Obesity appears more often in younger men (younger than 45 years) and in older women (older than 45 years) (30). In our research the oldest women had higher body mass indexes compared to women in twenties and thirties, while levels of visceral fat started to be elevated in women older than 40 .

The most important finding of our study is that although physical activity positively affected subjects' body weight and cardiorespiratory fitness, it could not prevent the effects of aging and hormone changes on a number of CVD risk factors. After the age of 40 and especially after the age of 50, women experienced significant rise of cardiovascular risk factors no matter if they exercised or not.

The results of this cross sectional research show that there is no significantly positive effect of exercise on cardiovascular risk profile of aging women. The limitation of our study relates to the knowledge about severity of exercise trainings of these women, since there are no written documents about their exercise programs in the fitness centre, but only the data about their regularity on trainings. Prospective design of the study in the controlled conditions would help in achieving the aim of our study more securely. For example, regular programmed exercise can prevent or delay adverse cardiovascular events in postmenopausal women. Further investigations of our research team may support this hypothesis.

\section{REFERENCES}

1. Stramba-Badiale M, Fox KM, Priori SG, et al. Cardiovascular diseases in women: a statement from the policy conference of the European Society of Cardiology. Eur Heart J 2006; 27: 994-1005.

2. Ignarro LJ, Balestrieri ML, Napoli C. Nutrition, physical activity, and cardiovascular disease: An update. Cardiovasc Res 2007; 73: 326-40.

3. Morris JN, Heady JA. Mortality in relation to the physical activity of work: a preliminary note on experience in middle age. Br J Ind Med 1953; 10: 245-54.

4. Morris JN, Heady JA, Raffle PA, et al. Coronary heartdisease and physical activity of work. Lancet 1953; 265: 1111-20.

5. Blair SN, Kampert JB, Kohl HW, et al. Influences of cardiorespiratory fitness and other precursors on cardiovascular disease and all-cause mortality in men and women. J Am Med Assoc 1996; 276: 205-10.

6. Blair SN, Kohl HW, Paffenbarger RS, Clark DG, Cooper KH, Gibbons LW. Physical fitness and allcause mortality: a prospective study of healthy men and women. J Am Med Assoc 1989; 262: 2395-401.

7. Paffenbarger RS, Hyde RT, Wing AL, Hsieh CC. Physical activity, all-cause mortality, and longevity of college alumni. N Engl J Med 1986; 314: 605-63.

8. Paffenbarger RS, Hyde RT, Wing AL, Lee IM, Jung DL, Kampert JB. The association of changes in physical-activity level and other lifestyle characteristics with mortality among men. N Engl J Med 1993; 328: 538-45.

9. Thompson PD, Buchner D, Piña IL, et al. American Heart Association Council on Clinical Cardiology Subcommittee on Exercise, Rehabilitation, and Prevention; American Heart Association Council on Nutrition, Physical Activity, and Metabolism Subcommittee on Physical Activity. Exercise and physical activity in the prevention and treatment of atherosclerotic cardiovascular disease: a statement from the Council on Clinical Cardiology (Subcommittee on Exercise, Rehabilitation, and Prevention) and the Council on Nutrition, Physical Activity, and Metabolism (Subcommittee on Physical Activity). Circulation 2003; 107: 3109-16.

10. Warburton DE, Nicol CW, Bredin SS. Health benefits of physical activity: the evidence. CMAJ 2006; 174 : 801-9.

11. Oguma Y, Sesso HD, Paffenbarger RS Jr, et al. Physical activity and all cause mortality in women: a review of the evidence. Br J Sports Med 2002; 36: 162-72. 
12. Myers J, Prakash M, Froelicher V, Do D, Partington S, Atwood JE. Exercise capacity and mortality among men referred for exercise testing. N Engl J Med 2002; 346: 793-801.

13. Morris JN, Clayton DG, Everitt MG, Semmence AM, Burgess EH. Exercise in leisure time: coronary attack and death rates. Br Heart J 1990; 63: 325-34.

14. Manini TM, Everhart JE, Patel KV, et al. Daily activity energy expenditure and mortality among older adults. J Am Med Assoc 2006; 296: 171-9.

15. Erikssen G. Physical fitness and changes in mortality: the survival of the fittest. Sports Med 2001; 31: 571-6.

16. Bello N, Mosca L. Epidemiology of coronary heart disease in women. Prog Cardiovasc Dis 2004; 46: 287-95.

17. Cooper CB, Storer TW. Estimation of VO2max from predictive tests. In: Cooper CB, Storer TW, eds. Exercise testing and interpretation. Cambridge: Cambridge University Press, 2004: 214-5.

18. Borg GA. Psychophysical bases of perceived exertion. Med Sci Sports Exerc 1982; 14: 377-81.

19. Grundy SM, Pasternak R, Greenland P, Smith S, Fuster $\mathrm{V}$. Assessment of cardiovascular risk by use of multiple-risk-factor assessment equations. a statement for healthcare professionals from the American Heart Association and the American College of Cardiology. Circulation 1999; 100: 1481-92.

20. Fletcher GF, Balady G, Amsterdam EA, Chaitman B, Eckel R, Fleg J. Exercise standards for testing and training: a statement for healthcare professionals from the American Heart Association. Circulation 2001; 104: 1694-740.

21. Hardman AE, Stensel DJ. Physical activity and health: the evidence explained. New York: Routledge, 2009.
22. Bassuk SS, Manson JE. Epidemiological evidence for the role of physical activity in reducing risk of type 2 diabetes and cardiovascular disease. J Appl Physiol 2005; 99: 1193-204.

23. Duncan GE, Perri MG, Anton SD, et al. Effects of exercise on emerging and traditional cardiovascular risk factors. Prev Med 2004; 39: 894-902.

24. Whelton SP, Chin A, Xin X, He J. Effect of aerobic exercise on blood pressure: a meta analysis of randomized, controlled trials. Ann Int Med 2002; 136: 493-503.

25. Cornelissen VA, Fagard RH. Effects of endurance training on blood pressure, blood pressure-regulating mechanisms, and cardiovascular risk factors. Hypertension 2005; 46: 667-75.

26. Slentz CA, Houmard JA, Johnson JL, et al. Inactivity, exercise training and detraining, and plasma lipoproteins: STRRIDE: a randomized, controlled study of exercise intensity and amount. J Appl Physiol 2007; 103: 432-42.

27. Di Francescomarino S, Sciartilli A, Di Valerio V, Di Baldassarre A, Gallina S. The effect of physical exercise on endothelial function. Sports Med 2009; 39: 797-812.

28. Collins P, Rosano G, Casey C, et al. Management of cardiovascular risk in the peri-menopausal woman: a consensus statement of European cardiologists and gynaecologists. Eur Heart J 2007; 28: 2028-40.

29. Kannel WB. Metabolic risk factors for coronary heart disease in women: perspective from the Framingham Study. Am Heart J 1987; 114: 413-9.

30. Mokdad AH, Ford ES, Bowman BA, et al. Prevalence of obesity, diabetes, and obesity-related health risk factors, 2001. JAMA 2003; 289: 76-9. 